
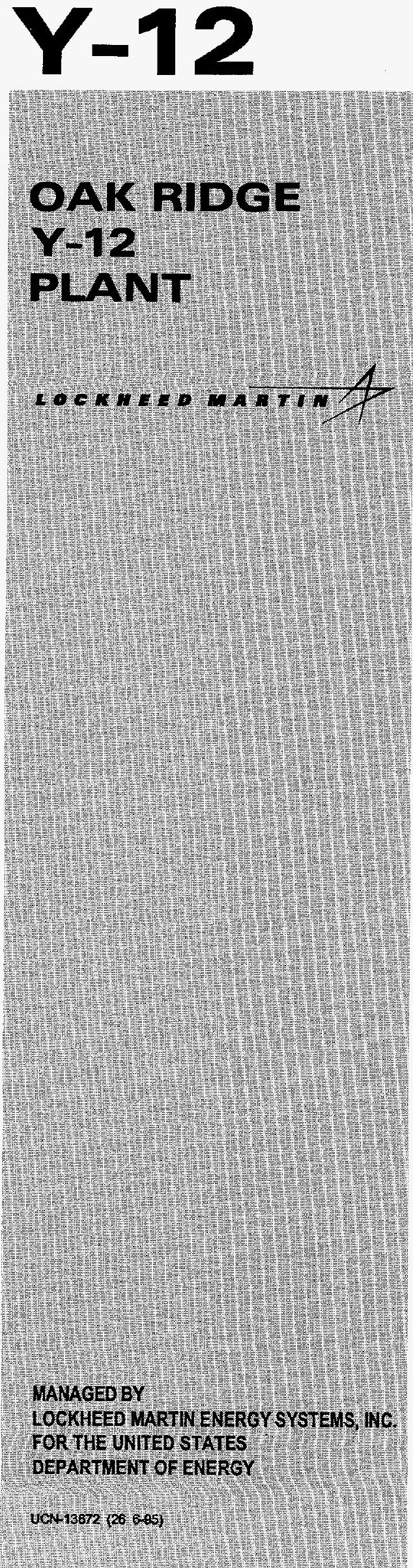

RECEIVED

FEB $2 \% 1998$

YIAMT-478
Project Accomplishment Summary
for
Project Number 92-MULT-020-B2-0

\section{TESTING OF HIGH SPEED NETWORK COMPONENTS}

W. R. Wing

Lockheed Martin Energy Systems, Inc.

Telecommunications and Computer Technologies Corporation

June 30, 1997

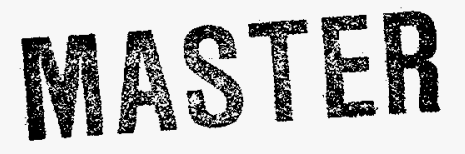

Approved for Public Release; distribution is unlimited.

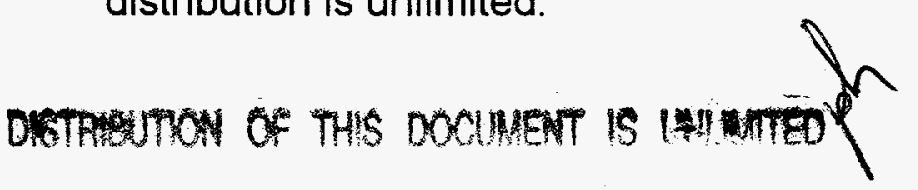

Prepared by the

Oak Ridge Y-12 Plant managed by

LOCKHEED MARTIN ENERGY SYSTEMS, INC. for the

U.S. DEPARTMENT OF ENERGY under contract DE-AC05-84OR21400 


\section{DISCLAIMER}

This report was prepared as an account of work sponsored by an agency of the United States Government. Neither the United States Government nor any agency thereof, nor any of their employees, make any warranty, express or implied, or asumes any legal liability or responsibility for the accuracy, completeness, or usefulness of any information, apparatus, product, or process disclosed, or represents that its use would not infringe privately owned rights. Reference herein to any specific commercial product, process, or service by trade name, trademark, manufacturer, or otherwise does not necessarily constitute or imply its endorsement, recommendation, or favoring by the United States Government or any agency thereof. The views and opinions of authors expressed herein do not necessarily state or reflect those of the United States Government or any agency thereof. 


\section{DISCLAIMER}

Portions of this document may be illegible electronic image products. Images are produced from the best available original document. 


\section{PROJECT ACCOMPLISHMENT SUMMARY}

Title: $\quad$ Testing of High-Speed Network Components

DOE TTI Number: 92-MULT-020B2-0

CRADA Number: ORNL91-0069 and ORNL92-0124

Partner:

Telecommunications and Computer Technologies Corporations

\section{BACKGROUND}

At the time of the start of this project, a battle was being fought between the computer networking technologies and telephone networking technologies. The telecommunications industry wanted to standardize on Asynchronous Transfer Mode (ATM) as the technology of choice for carrying all cross-country traffic. The computer industry wanted to use Packet Transfer Mode (PTM). The chief distinction between these is that ATM is based on fixed-size, small (48-byte payload) cells whereas packets have varying size, with as much as 8 kilobytes of payload available in some implementations. Switches able to deal with packets would be significantly more expensive than switches designed for handling cells. However, computer data can be handled much more efficiently with packets, thus both groups focused on solutions optimized for their own needs. Since all cross country traffic (including voice) is digital today, the issue was fundamental. The computer industry had invested considerable effort in developing a PTM switch which it felt was demonstrably superior to ATM. Both the telecommunications and the computer technology industries were looking for a test site, which would offer a tightly controlled, high technology environment, where the PTM and ATM technologies could be tested in near real world conditions. They needed a location with computer networks supporting sufficiently demanding loads to provide a realistic test, where there were sophisticated network experts who could participate in the tests, and finally, which covered a sufficiently large geographic area to provide a good simulation of a metropolitan environment. The Oak Ridge/Knoxville local dialing area provided such a location. The plan was to extend the test network all the way to the University of Tennessee in Knoxville (where there is research staff with joint UT/ORNL appointments). The total extent of the network, from $\mathrm{K}-25$ to Knoxville would more than provide a metro-scale test.

\section{DESCRIPTION}

The project had several goals, some unspoken. At the highest, most obvious level, the project goals were to test the high-speed components being developed by the computer technology industry. However, in addition, both industrial partners were having trouble finding markets for the high-speed networking technology they were developing and deploying. Thus, a part of the project was to demonstrate applications developed at Oak Ridge which would stretch the limits of the network, and thus demonstrate the utility of high-speed networks. Finally, an unspoken goal of the computer technology industry was to convince the telecommunications industry that packet switching was superior to cell switching. Conversely, the telecommunications industry hoped to see the computer technology industry's packet switch fail to perform in a real-world test.

\section{BENEFITS TO DOE}

Ultimately, the computer technology industry failed to deliver a working switch, and the project 
was terminated without demonstrating running applications. However, even in the absence of such a switch (or switches), the benefits to DOE were substantial. Both the Y-12 and X-10 sites had spent General Plant Project (GPP) funds to build backbone fiber networks within their respective campuses. In parallel, the Oak Ridge Federal Integrated Communications Network project (ORFICN) was installing fiber to interconnect the three Oak Ridge sites. However, the ORFICN project fiber didn't become available for use until July of 1996 and even then, there was no fiber to off-site locations. Thus, there were no facilities available for high-speed network connections between Oak Ridge sites, to other DOE sites, or to the Internet. This project installed fiber that supported those connections. At the time this project was started, the entire Oak Ridge complex was networked to the rest of DOE by two T1 connections for an aggregate capacity of three megabits per second. Because there was no fiber connecting off-site, there was no way to increase this capacity to support improved connections to the Western Labs, to Headquarters, to the Internet, and even (then) between the sites in Oak Ridge. Starting in the spring of 1994, fiber installed by this project allowed Oak Ridge's connection to ESnet (and to the Internet) to be improved from a pair of $\mathrm{T} 1$ connections $(3 \mathrm{Mb} / \mathrm{s})$ to $\mathrm{T} 3(45 \mathrm{Mb} / \mathrm{s})$. Currently that connection has been improved again, this time to OC $3(155 \mathrm{Mb} / \mathrm{s})$. It is still being carried on fiber installed by this project, and will continue to be for some time to come. The high-speed SecureNet connection into and out of $\mathrm{Y}-12$ is being carried on this fiber today.

\section{ECONOMIC IMPACT}

Not applicable

\section{PROJECT STATUS}

Project was terminated early due to failure of one of the CRADA partners to deliver need componet.

\section{DOE FACILITY POINT(S) OF CONTACT FOR PROJECT INFORMATION:}

W. R. Wing

Lockheed Martin Energy Research

P.O. Box 2009

Oak Ridge, TN 37831-6144

Phone (423) 574-8839, FAX (423) 574-1001

\section{COMPANY SIZE AND POINT(S) OF CONTACT:}

Both industrial partners are multi-billion dollar corporations who object to the use of their corporate names in this report.

\section{PROJECT EXAMPLES}

Not applicable

TECHNOLOGY COMMERCIALIZATION

Not applicable 


\section{Distribution}

W. R. Wing, MS-6144, 4500-S

Ray Ford, MS-8084, 9203

Joyce Shepherd, MS-6416, 5002

Andy Stevens/DOE OR, MS-8009, 9704-2

Diane Bird, DOE DP-17

Bill Wilburn, MS-8015, 9704-2

Lab Records, MS-6285, 4500-N

Y-12 Central Files, MS-8169, 9711-5 (3 copies) 